\title{
Milliequivalent per Microliter
}

National Cancer Institute

\section{Source}

National Cancer Institute. Milliequivalent per Microliter. NCI Thesaurus. Code C70578.

A concentration unit measured as a number of milliequivalents of solute per microliter of solution. 